\title{
The control of fermentation of carbohydrate
}

\author{
By A. G. Singleton, Sub-Department of Veterinary Physiology, \\ University of Liverpool $L 69{ }_{3} B X$
}

\begin{abstract}
Although ruminants have many nutritional advantages, one of the disadvantages of fermentation preceding digestion is that starches and sugars are, at least in part, changed to volatile fatty acids, thus reducing the amount of glucose which can be produced by digestion in the duodenum and making the animal more dependent on gluconeogenesis to supply metabolic glucose.

Attempts to manipulate or control carbohydrate fermentation might be aimed at changing its quality or quantity. Qualitative changes can be achieved by varying other components of the diet, particularly if they affect the micro-organisms, and may result in different end products of fermentation, which may or may not be advantageous. Quantitative changes would increase or reduce the amount of ruminal fermentation and they would be achieved either by changing the rumen retention time, or the rate of fermentation. Increased fermentation could increase the digestibility of fibre; decreased fermentation might allow more starch to be passed on to the duodenum.
\end{abstract}

Ten years ago it was generally believed that little or no soluble carbohydrate survived fermentation in the rumen and that the quantity of glucose available for absorption from the intestine was of little significance, whether derived from dietary starch or microbial polysaccharide. This view was based on two lines of evidence. Heald (195I) had estimated that the microbial polysaccharide entering the duodenum of a sheep fed only on hay would provide only about $5 \mathrm{~g} / \mathrm{d}$ of glucose, and measurements of glucose in portal-venous and arterial blood (Schambye, I95 r ; Lewis, Hill \& Annison, 1957) had shown only small differences.

Ridges \& Singleton (1962) reported the results of some quantitative experiments in goats fed on hay and concentrates, in which duodenal flow had been measured electromagnetically, and food, duodenal contents and faeces had been analysed for proximate constituents. They found that about $7 \circ \mathrm{g} / \mathrm{d}$ of the crude fraction, called soluble carbohydrate, by difference, or nitrogen-free extract, apparently disappeared from the intestines. Although this fraction would include pentosans, the possibility was indicated that some starch might enter the duodenum. They also calculated that even if all this material yielded glucose, the absorption of this quantity in $24 \mathrm{~h}$ would require portal-arterial differences of only $0.2 \mathrm{mmol} / \mathrm{l}$, assuming a portal blood flow of $4^{\circ} \mathrm{ml} / \mathrm{min}$ per $\mathrm{kg}$ live weight (Schambye, 1956; Fegler \& Hill, 1958) and this was within the range reported by Schambye (195 I). 
Since then, many workers have performed quantitative experiments on sheep and cattle, and some results were reviewed by Armstrong \& Beever (I969) at a previous symposium of this Society. They calculated that the quantity of starch disappearing from the intestine of sheep whose diet included ground maize was more than enough to provide the daily glucose requirement and, in sheep, given flaked maize the quantity was less, but still an appreciable contribution. This assumed the starch to be digested by host enzymes and absorbed as glucose. This difference between flaked and ground maize provides one method of manipulation.

Porter \& Singleton (1966) reported that in three sheep given $4^{\circ 0} \mathrm{~g} / \mathrm{d}$ commercial concentrate, plus hay to appetite, the quantity of starch apparently disappearing from the intestine seemed to be influenced by the amount of hay eaten. In two sheep eating 700 and $1000 \mathrm{~g} / \mathrm{d}$ hay, about $10-12 \%$ of the digestible starch seemed to disappear from the intestine, whereas in a third sheep eating $1300 \mathrm{~g} / \mathrm{d}$ hay, over $50 \%$ apparently disappeared from the intestine. Also in this sheep the proportions of digestible cellulose and pentosan disappearing from the intestine were greatly increased (Table I). It appeared that this sheep had increased his ruminal throughput by decreasing ruminal retention-time, and that this shifted some of the fibre

Table I. Percentage of digestible carbohydrate fractions disappearing from stomach and intestines in three sheep given daily a commercial concentrate plus hay to appetite

\begin{tabular}{|c|c|c|c|c|c|c|c|}
\hline \multirow{2}{*}{$\begin{array}{l}\text { Hay } \\
\text { (g) }\end{array}$} & \multirow{2}{*}{$\begin{array}{c}\text { Concentrate } \\
\text { (g) }\end{array}$} & \multicolumn{2}{|c|}{ Cellulose } & \multicolumn{2}{|c|}{ Pentosan } & \multicolumn{2}{|c|}{ Starch } \\
\hline & & Stomach & Intestine & Stomach & Intestine & Stomach & Intestine \\
\hline 1300 & 400 & $9 I \cdot 6$ & $8 \cdot 4$ & $79 \cdot 8$ & $20 \cdot 2$ & $45^{\prime} I$ & 54.9 \\
\hline 1000 & 400 & $98 \cdot 5$ & $1 \cdot 5$ & $91 \cdot 1$ & $8 \cdot 9$ & $89 \cdot 6$ & 10.6 \\
\hline 700 & 400 & $97 \cdot 2$ & $2 \cdot 8$ & $9^{8 \cdot 0}$ & $2 \cdot 0$ & $87 \cdot 1$ & $12 \cdot 9$ \\
\hline
\end{tabular}

fermentation from rumen to intestine. We have found in almost all our experiments (e.g. Porter \& Singleton, I97I) that the fermentation capacity of the large intestine is hardly utilized, in that $95^{-100 \%}$ of digestible cellulose and pentosan disappears from the rumen. Sometimes, when ruminal efficiency is impaired, for example by recurrent blocking of a re-entrant fistula, food intake is decreased and the proportion of fibre digested in the intestine is increased, though total digestibility is about the same. This suggests that if we increase the rate of passage through the rumen, we can increase the amount of starch entering the duodenum, without necessarily impairing the digestion of the fibre polysaccharides. The intestine provides a reserve of fermentative capacity, the efficiency of which would probably increase if more fermentable material were presented to it. It is probable that an increased rate of fermentation would be required, since an increased rate of passage through the rumen must be accompanied by an increased rate through the intestine.

It is interesting to note that this type of manipulation seems to occur naturally in pregnancy. Rumen capacity is progressively reduced as the uterine volume increases and food intake is maintained by decreasing ruminal retention time (Graham \& Williams, 1962; Forbes, 1970). In view of the increased glucose requirement in 
pregnancy, it would be interesting to know if the quantity of starch entering the duodenum is also increased.

Recently, Potter, Walker \& Forrest (I 972) have reported the effects of supplying hypertonic $\mathrm{NaCl}(\mathrm{I} \cdot 3 \%)$ solution instead of fresh water. Appetite was increased, and there was a more rapid passage of material through the rumen, as assessed by polyethylene glycol marker. Walker, Potter \& Jones (197r) had shown that this treatment produced metabolic changes, as judged by changes in carcass composition.

It is important to remember that experimental results which indicate that a particular quantity of starch is presented to the duodenum, or even show that it apparently disappears from the small intestine, do not necessarily mean that it is digested and absorbed as glucose. It could be subjected to microbial attack in the latter part of the small intestine. Orskov, Mayes \& Penn (197I) have produced evidence that the quantity of glucose, introduced through a duodenal cannula, which can be absorbed in a day may be limited, though their experimental conditions may not have been physiological. The glucose was added to isotonic $\mathrm{NaCl}$ solution in increasing quantities and thus the solution was always hypertonic, and may not have spent the usual length of time in the intestine. The limiting quantity of 300 $\mathrm{g} / \mathrm{d}$ for $50 \mathrm{~kg}$ sheep seems to be well above ordinary requirements.

Evidence is still required of portal-arterial differences in glucose level in serial samples in the period following a feed, combined with continuous or frequent measurements of portal blood flow.

\section{REFERENCES}

Armstrong, D. G. \& Beever, D. E. (1969). Proc. Nutr. Soc. 28, I 21.

Fegler, C. \& Hill, K. J. (1958). Q. Yl exp. Physiol. 43, r89.

Forbes, J. M. (1970). F. Anim. Sci. 31, 1222.

Graham, N. McC. \& Williams, A. J. (1962). Aust. F. agric. Res. r3, 894.

Heald, P. J. (195I), Br. F. Nutr. 5, 84.

Lewis, D., Hill, K. J. \& Annison, E. F. (I957). Biochem. F. 66, 587.

Orskov, E. R., Mayes, R. W. \& Penn, A. (1971). Proc. Nutr. Soc. 30, 43 A.

Porter, P. \& Singleton, A. G. (r966). F. Physiol., Lond. r86, 145P.

Porter, P. \& Singleton, A. G. (I97I). Br. F. Nutr. 26, 75.

Potter, B. J., Walker, D. J. \& Forrest, W. W. (1972). Br. F. Nutr. 27, 75.

Ridges, A. P. \& Singleton, A. G. (I962). F. Physiol., Lond. r6r, r.

Schambye, P. (I 95 I). Nord. VetMed. 3, 555.

Schambye, P. (1956). Nord. VetMed. 7, 1001.

Walker, D. J., Potter, B. J. \& Joncs, G. B. (1971). Aust. F. exp. Agric. Anim. Husb. II, I4. 